\title{
Effect of calcium sulfoaluminate additive on linear deformation at different humidity and strength of cement mortars
}

\author{
Kadhim Abdulwahid Al-Musawi ${ }^{1}$, Kottayil Bindhu Abraham ${ }^{2 *}$, Tatsiana Potses ${ }^{1}$, Leonovich \\ Sergey ${ }^{1}$, Beulah $M^{2}$, and Jerzy Obolewich ${ }^{3}$. \\ ${ }^{1}$ Belarusian National Technical University, Minsk, Belarus. \\ ${ }^{2}$ Christ (Deemed to be University), Bangalore, India. \\ ${ }^{3}$ Politechnika Bialostocka, Poland.
}

\begin{abstract}
The effect of calcium Sulfoaluminate additives (CSA) on the compression and bending strength of mortar, as well as linear deformation of prism samples at different environmental humidity was studied. Test results indicate that bending strength of mortars with CSA and the referent at the age of 28 days are practically equal. Compressive strength of mortars with CSA reduced by $20 \ldots 23 \%$ for all dosages of CSA. Relative linear deformations depend on the humidity of the environment. At a humidity of $100 \%$, the relative linear deformations are positive and the expansion increases with increasing dosage of the expanding additive. When hardening in dry air at a humidity of $55 \%$, the greatest shrinkage deformations were observed for mortars with CSA. We can conclude that the expanding effect of CSA is fully manifested at high humidity, i.e. under construction conditions, this means very high-quality moisture care for concrete structures.
\end{abstract}

Keywords: Shrinkage, cracks, calcium Sulfoaluminate additives, expanding additives.

\section{Introduction}

The issue of concrete durability is one of the main issues in modern construction. It is well known that one of the most significant factors affecting the durability and security of monolithic and prefabricated structures is the appearance and development of various kinds of cracks. Different types of cracks and their causes are described in detail in the literature $[1,2,3,4,5,8,9]$.

Generally, all cracks in concrete can be divided into 2 categories: cracks that appear in fresh concrete and cracks that appear after hardening of concrete.

Cracks in fresh concrete can appear as a result of plastic settlement and/or plastic shrinkage of concrete, as well as the result of both the movement of the formwork, foundation or other technological reasons. There are many reasons for cracking in hardened concrete.

*Corresponding author: bindhuabraham.23@gmail.com 
It can be chemical shrinkage (volume reduction due to cement hydration), autogenous shrinkage (typical for concrete with a low water/cement ratio), drying shrinkage (water loss of hardened concrete in an environment with low humidity). Shrinkage cracks can also be caused by temperature deformations of massive structures, by errors in structural design/manufacturing/ operation, corrosion of reinforcing bars (wedge effect of corrosion products), carbonization, etc.

It is obvious that depending on the composition, the conditions of hardening and care, the age of concrete, different types of shrinkage deformations will prevail. However, for ordinary concrete $(\mathrm{W} / \mathrm{C}>0.4)$ the most significant contribution to the shrinkage deformation of the structure is the drying shrinkage [2].

Three most effective ways to combat drying shrinkage can be [4]:

- Implementation of high-quality moisture care of the concrete structure;

- Compensation of shrinkage with the help of expanding mineral additives;

- Reduction of shrinkage due to Shrinkage Reducing Admixtures (SRA) based on glycols.

The use of the first method is of the most preferable, but it is not always feasible in construction.

Thus the most reliable and widespread way is the use of expanding mineral additives, that are used for concrete, mortar dry mixes, grouting etc. Expanding additives act due to the formation of ettringite (Sulfoaluminate additives) or calcium hydroxide (additives based on $\mathrm{CaO}$ ). Sulfoaluminate additives, which are safer for humans than CaO-based additives, are most prevalent in the world and in Belarus. CSA-expanding additives have been used since the 80 s of the last century [6]. Many years of experience in their use have revealed some of the disadvantages of using these modifiers. They are supplied only in dry form and have high dosages (usually $10 \%$ by weight of cement). There is also literature date that concrete with CSA expanding additives is very sensitive to the quality of moisture care. In this regard, this research is related to its study of the effect of humidity on the expanding potential of CSA-expanding additives.

\section{Experimental Investigation}

\section{Materials}

The properties of the materials used in the experiment are shown in the tables 1-5.

Table 1 - Cement

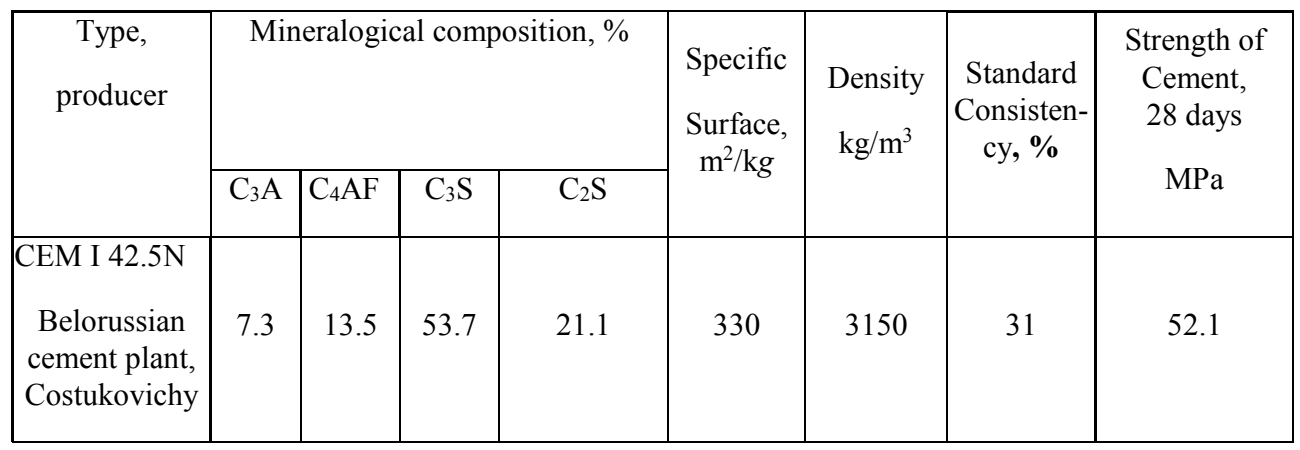


Table 2 - Fine aggregate

\begin{tabular}{|c|c|c|c|c|c|}
\hline Type, & $\begin{array}{c}\text { Modu- } \\
\text { lus of } \\
\text { fine- } \\
\text { ness }\end{array}$ & $\begin{array}{c}\text { Density, } \\
\mathrm{kg} / \mathrm{m}^{3}\end{array}$ & $\begin{array}{c}\text { Bulk } \\
\text { density, } \\
\mathrm{kg} / \mathrm{m}^{3}\end{array}$ & $\begin{array}{c}\text { Water } \\
\text { absorp- } \\
\text { tion, } \%\end{array}$ & $\begin{array}{c}\text { Specific } \\
\text { Surface, } \\
\mathrm{m}^{2} / \mathrm{kg}\end{array}$ \\
\hline Quarry sand, Crapugino & 3.25 & 2650 & 1660 & 0.66 & 8.9 \\
\hline
\end{tabular}

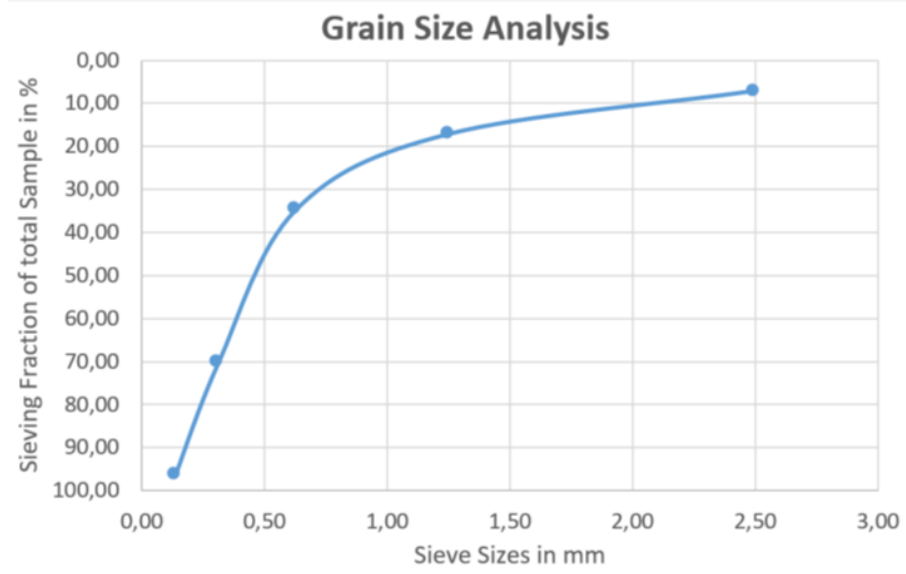

Figure 1 - Grain size distribution of used fine aggregate

Table 3 - Calcium Sulfoaluminate additive (CSA)

\begin{tabular}{|c|c|c|c|c|c|c|}
\hline \multirow{2}{*}{$\begin{array}{c}\text { Type, } \\
\text { producer }\end{array}$} & \multirow{2}{*}{$\begin{array}{c}\text { Hu- } \\
\text { midi- } \\
\text { ty, } \%\end{array}$} & \multirow{2}{*}{$\begin{array}{l}\text { Density, } \\
\mathrm{kg} / \mathrm{m}^{3}\end{array}$} & \multirow{2}{*}{$\begin{array}{c}\text { Specific } \\
\text { Surface, } \\
\mathrm{m}^{2} / \mathrm{kg}\end{array}$} & \multicolumn{3}{|c|}{ Content, \% } \\
\hline & & & & $\mathrm{Al}_{2} \mathrm{O}_{3}$ & $\mathrm{SO}_{3}$ & $\mathrm{Cl}$ \\
\hline $\begin{array}{l}\text { Expanding Sulfoaluminate } \\
\text { Modifier «ESAM», }\end{array}$ & $<0.1$ & 2850 & 450 & 10 & 30 & $<0.1$ \\
\hline
\end{tabular}

Table 4 - Polycarboxylate-based admixture Relamix PK

\begin{tabular}{|l|c|c|c|}
\hline \multicolumn{1}{|c|}{$\begin{array}{c}\text { Type, } \\
\text { producer }\end{array}$} & $\mathrm{pH}$ & $\begin{array}{c}\text { Density, } \\
\mathrm{kg} / \mathrm{m}^{3}\end{array}$ & $\begin{array}{c}\text { Dry con- } \\
\text { tent, } \%\end{array}$ \\
\hline $\begin{array}{l}\text { Polycarboxylate-based admixture Relamix PK, } \\
\text { Polyplast }\end{array}$ & 8.2 & 1080 & 30 \\
\hline
\end{tabular}


Table 5 - Water

\begin{tabular}{|c|c|c|c|}
\hline \multicolumn{4}{|c|}{ Content, $\mathrm{mg} / \mathrm{l}}$, \\
\hline Soluble salts & $\mathrm{SO}_{4}{ }^{-2}$ & $\mathrm{Cl}^{-1}$ & Suspended particles \\
\hline$<3000$ & $<2000$ & $<600$ & $<200$ \\
\hline
\end{tabular}

\section{Experimental Methods}

Prism samples for determining compressive and bending strength, linear deformation were made in accordance with the requirements of Self-stressing cement - technical conditions - 1335 [7]. In accordance with Self-stressing cement - technical conditions - 1335, the ratio of cement/sand=1. All compositions had the same water/binder ratio and workability, which was achieved due to the adding of the polycarboxylate-based admixture Relamix PK into the mortar mixture.

\subsection{Experimental Program}

Table 6 - Experimental program

\begin{tabular}{|c|c|c|c|c|}
\hline № & Modifier & $\mathrm{W} / \mathrm{B}$ & $\begin{array}{c}\text { Dosage CSA, \% by } \\
\text { weight of Binder }\end{array}$ & Storage \\
\hline 1.1 & Referent (without CSA) & 0.3 & & \multirow{4}{*}{$\begin{array}{l}\text { Storage at humidity } \\
55 \% \pm 5\end{array}$} \\
\hline 2.1 & \multirow{3}{*}{ CSA } & \multirow{3}{*}{0.3} & 5 & \\
\hline 2.2 & & & 10 & \\
\hline 2.3 & & & 15 & \\
\hline 10.1 & Referent (without CSA) & 0.3 & & \multirow[t]{4}{*}{ Storage in the water } \\
\hline 20.1 & \multirow{3}{*}{ CSA } & 0.3 & 5 & \\
\hline 20.2 & & 0.3 & 10 & \\
\hline 20.3 & & 0.3 & 15 & \\
\hline
\end{tabular}

\subsection{Experimental Results}

The results of experimental studies are shown in tables 7 - 11 and Figures 2-5.

Table 7 - Results of Cone Spread

\begin{tabular}{|c|c|c|c|c|c|c|c|}
\hline \multicolumn{2}{|c|}{ NO } & $\begin{array}{c}\text { Cement } \\
(\mathrm{gm})\end{array}$ & $\begin{array}{c}\text { Sand } \\
(\mathrm{gm})\end{array}$ & CSA(\%) & $\begin{array}{c}\text { Water } \\
(\mathrm{gm})\end{array}$ & $\begin{array}{c}\text { W/Binder } \\
\text { ratio }\end{array}$ & $\begin{array}{c}\text { Cone } \\
\text { Spread } \\
(\mathrm{mm})\end{array}$ \\
\hline 1.1 & 10.1 & 1000 & 1000 & - & 150 & 0.3 & 113 \\
\hline 2.1 & 20.1 & 1000 & 1000 & 5 & 150 & 0.3 & 111 \\
\hline 2.2 & 20.2 & 1000 & 1000 & 10 & 150 & 0.3 & 110 \\
\hline 2.3 & 20.3 & 1000 & 1000 & 15 & 150 & 0.3 & 108 \\
\hline
\end{tabular}


Table 8 - Flexural strength

\begin{tabular}{|c|c|c|c|}
\hline \multirow{2}{*}{ No } & \multicolumn{3}{|c|}{ Flexural strength, MPa at age, days } \\
\cline { 2 - 4 } & 1 & 3 & 28 \\
\hline Referent & 4.8 & 6.52 & 9.1 \\
\hline $5 \% \mathrm{CSA}$ & 5.6 & 6.7 & 8.9 \\
\hline $10 \% \mathrm{CSA}$ & 5.5 & 6.9 & 8.2 \\
\hline $15 \% \mathrm{CSA}$ & 5.9 & 7 & 9.2 \\
\hline
\end{tabular}

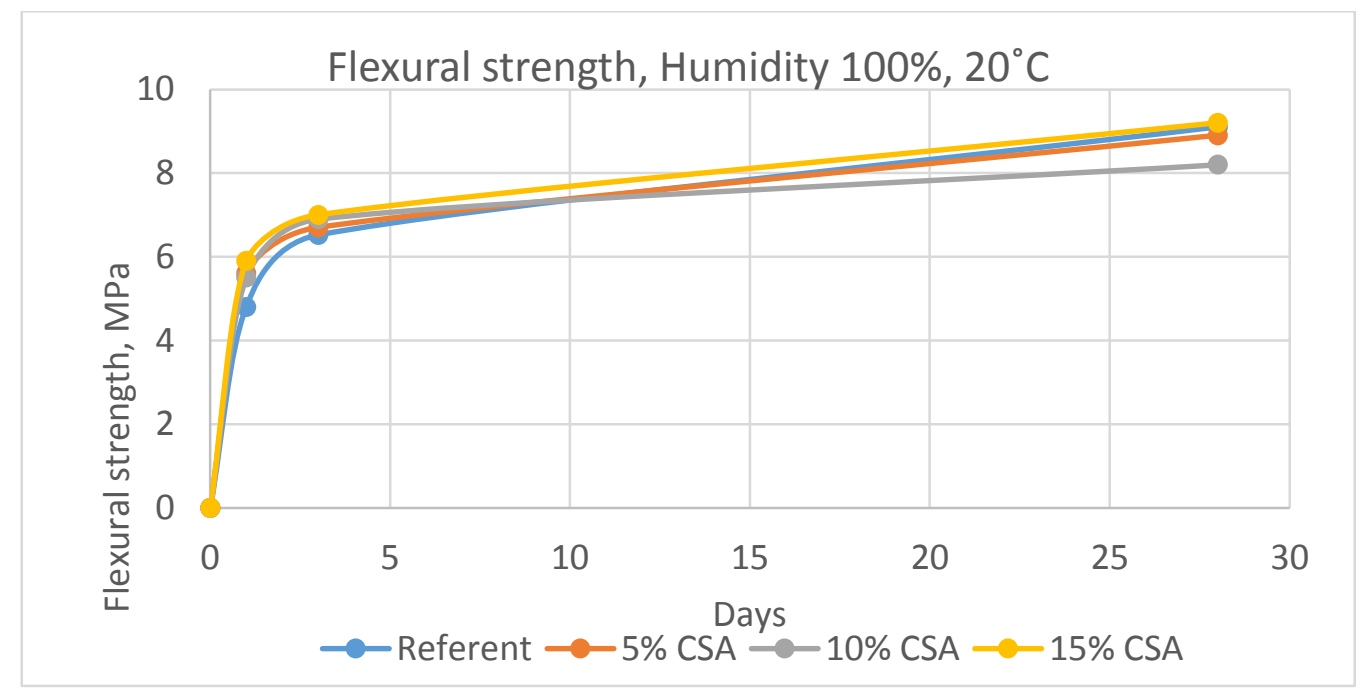

Figure 2 - Flexural strength results

Table 9 - Compressive strength

\begin{tabular}{|c|c|c|c|}
\hline \multirow{2}{*}{ No } & \multicolumn{3}{|c|}{ Compressive strength, MPa at age, days } \\
\cline { 2 - 4 } & 1 & 3 & 28 \\
\hline Referent & 33 & 54.1 & 65.5 \\
\hline $5 \% \mathrm{CSA}$ & 32.2 & 50 & 52.1 \\
\hline $10 \% \mathrm{CSA}$ & 29.5 & 46.8 & 51.8 \\
\hline $15 \% \mathrm{CSA}$ & 28.5 & 42.8 & 49.9 \\
\hline
\end{tabular}




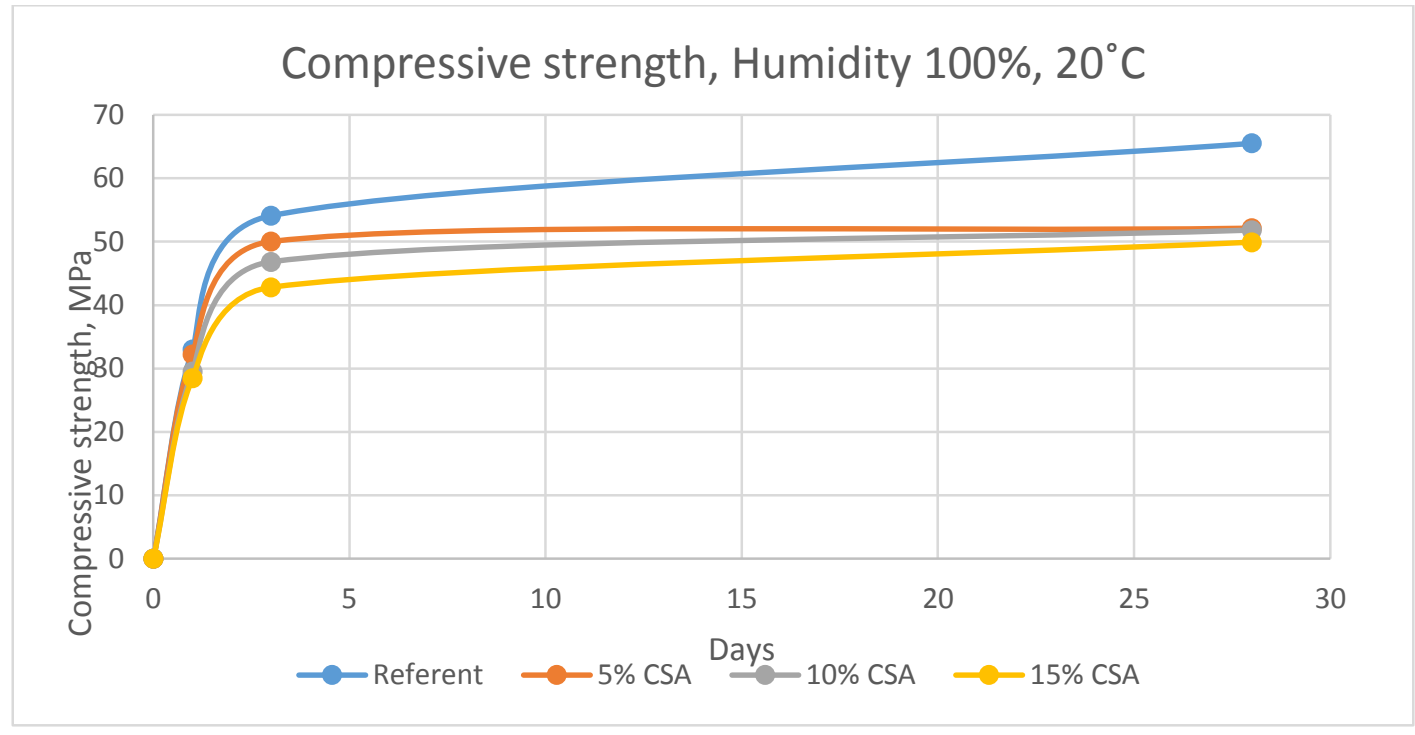

Figure 3 - Compressive strength results

Table 10 - Relative Linear Deformation Humidity $55 \%$

\begin{tabular}{|c|c|c|c|c|c|c|c|}
\hline \multirow{2}{*}{ No } & \multicolumn{7}{|c|}{ Relative Linear Deformation, \% } \\
\cline { 2 - 8 } & 1 & 2 & 3 & 7 & 14 & 20 & 28 \\
\hline Referent & 0 & 0.006 & -0.03 & -0.045 & -0.04 & -0.03 & -0.02 \\
\hline $5 \%$ CSA & 0 & 0.01 & -0.065 & -0.09 & -0.065 & -0.065 & -0.062 \\
\hline $10 \%$ CSA & 0 & 0.012 & -0.066 & -0.093 & -0.049 & -0.054 & -0.051 \\
\hline $15 \%$ CSA & 0 & 0.015 & -0.085 & -0.12 & -0.1 & -0.07 & -0.07 \\
\hline Referent & 0 & 0.01 & -0.065 & -0.09 & -0.065 & -0.065 & -0.06 \\
\hline
\end{tabular}

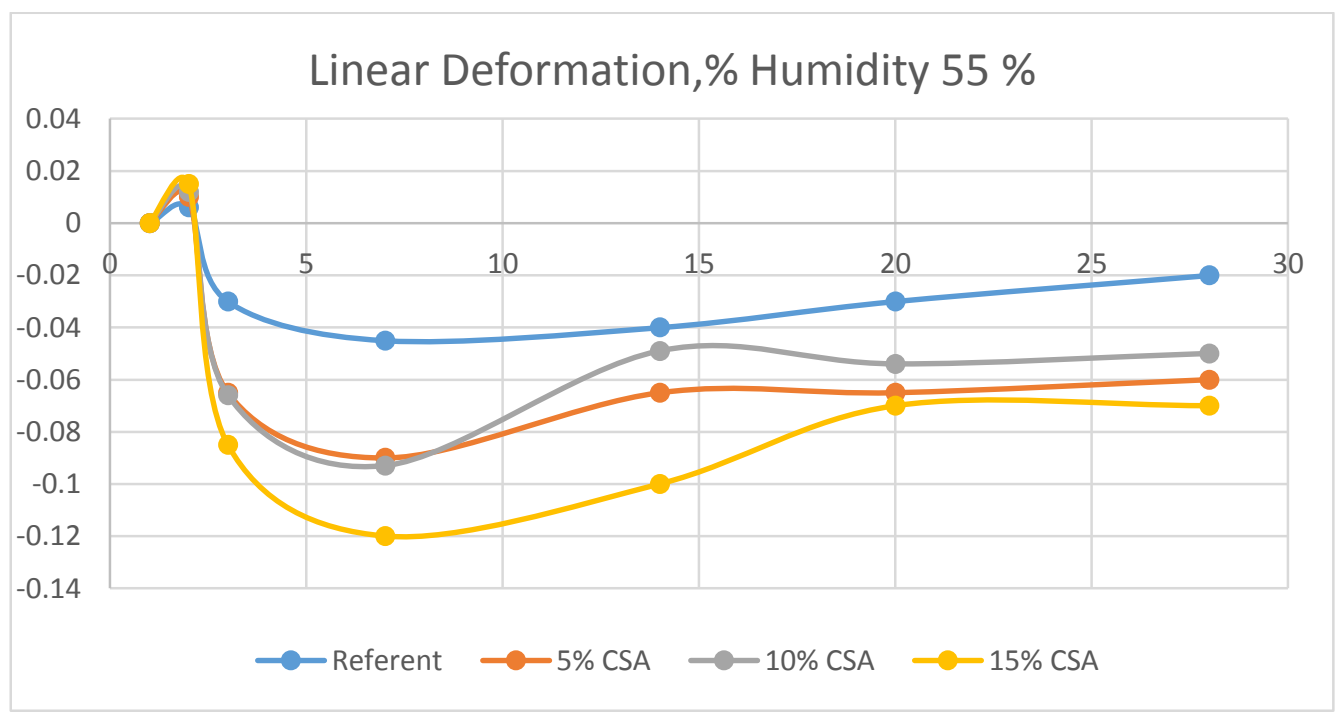

Figure 4 - Relative Linear Deformation at Humidity $55 \%$ 
Table 11 - Relative Linear Deformation Humidity $100 \%$

\begin{tabular}{|c|c|c|c|c|c|c|c|}
\hline \multirow{2}{*}{ No } & \multicolumn{7}{|c|}{ Relative Linear Deformation, \% } \\
\cline { 2 - 8 } & 1 & 2 & 3 & 7 & 14 & 20 & 28 \\
\hline Referent & 0 & 2 & 3 & 7 & 10 & 14 & 28 \\
\hline $5 \%$ CSA & 0 & 0.0889 & 0.1 & 0.12 & 0.05 & 0.03 & 0.01 \\
\hline $10 \%$ CSA & 0 & 0.13 & 0.19 & 0.27 & 0.27 & 0.25 & 0.2 \\
\hline $15 \%$ CSA & 0 & 0.17 & 0.19 & 0.32 & 0.32 & 0.27 & 0.23 \\
\hline
\end{tabular}

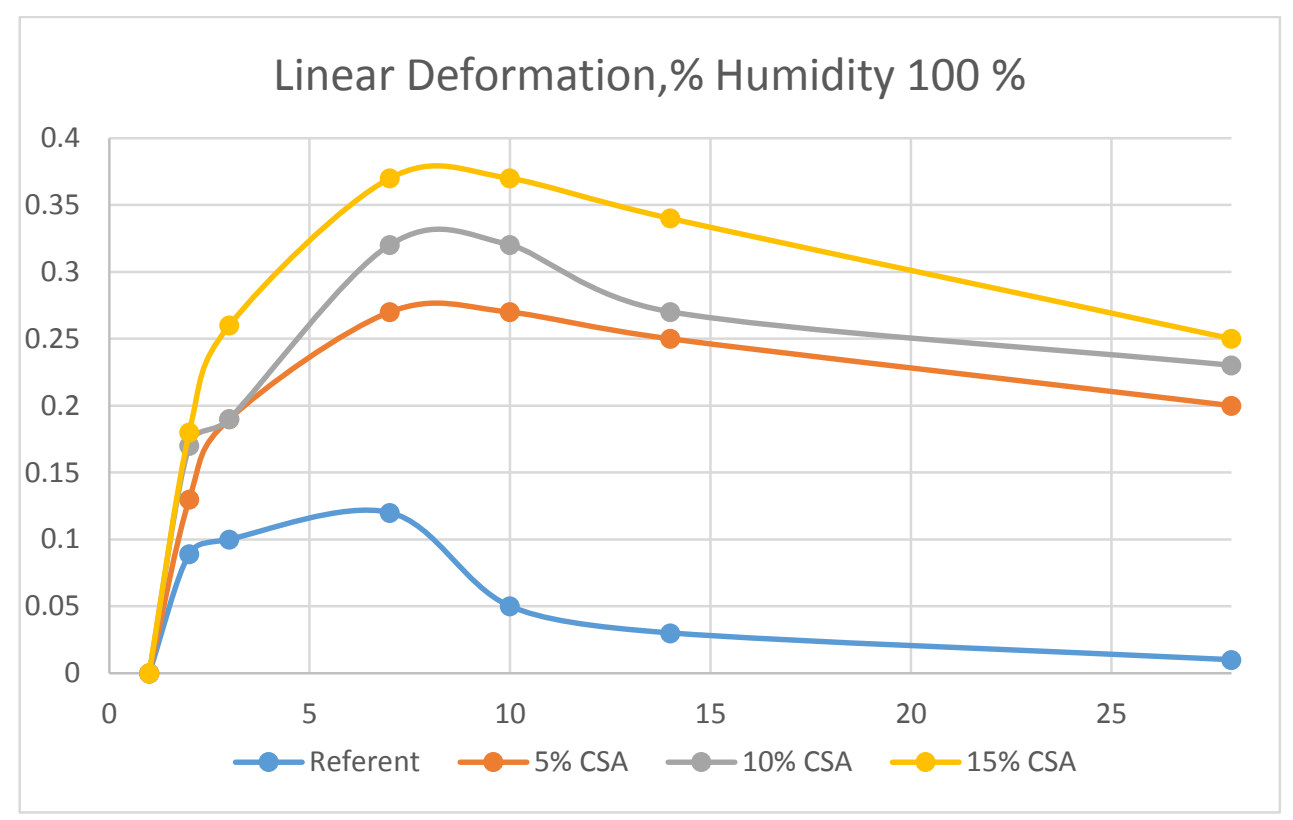

Figure 5 - Relative Linear Deformation at Humidity $100 \%$

\section{Conclusions}

1. The initial stage of the study on the influence of expanding additives on the crack resistance of concrete is to determine the effect of Sulfoaluminate based additives on the main properties of a mortar - compression and bending strength, as well as linear deformation of prism samples at different environmental humidity.

2. As a result of the work, the following patterns were identified:

- Bending strength of mortars with CSA increased at the age of 1-3 days by $12.5 \ldots 20 \%$ compared with referent mortar. Moreover, the strengths at the age of 28 days of mortars with CSA and the referent are practically equal.

- Compressive strength of mortars with CSA reduced by $20 . . .23 \%$ for all dosages of CSA.

- Relative linear deformations depend on the humidity of the environment. At a humidity of $100 \%$, the relative linear deformations are positive and the expansion increases with increasing dosage of the expanding additive. Peak expansion occurs on 5...10 days of hardening. 
- When hardening in dry air at a humidity of 55\%, the greatest shrinkage deformations are characteristic for mortars with CSA. Moreover, with an increase in CSA dosage, shrinkage increases.

- Based on the results of shrinkage deformations, we can conclude that the expanding effect of CSA is fully manifested at high humidity, i.e. under construction conditions, this means very high-quality moisture care for structures.

In the case of hardening of structures in low humidity, i.e. when it is impossible to provide high-quality moisture care, for example, for vertical structures, the use of expanding additives is impractical and harmful.

\section{References}

1. ACI committee 224 "Control of cracking in concrete structures" ACI- 224-R American concrete institute, Farmington Hills MI, 2011.

2. Physical and mechanical properties of heavy self-compacting concrete: dissertation for the degree of candidate of technical sciences: specialty 05.23.05 Building materials and products / Kotov Dmitry Svyatoslavovich; scientific adviser Bleshchik NP; Research Republican Unitary Enterprise for Construction "Institute BelNIIS".

3. Collepardi M., Borsoi A., Collepardi S., Olagot J.J.O., Troli R. Effects of shrinkage reducing admixture in shrinkage compensating concrete under non-wet curing conditions // Cement and Concrete Composites. Vol.27, Issue 6. - 2005. - Pp. 704-708.

4. 4. N.N. Kalinovskaya, D.S. Kotov, E.V. Shcherbitskaya Shrinkage deformations of modified concrete. Causes and remedies // Bulletin of Polotsk State University. Series F. Construction. Applied Sciences. - 2018.No. 8. - S. 43-48.

5. 5. N.N. Kalinovskaya, D.S. Kotov, E.A. Ivanova Durability of concrete. Analysis of the causes and methods of reducing the shrinkage deformations of modified concrete. Tekhnologii betonov. - 2017. - No. 11-12 (136-137). - S. 14-17.

6. Ramachandran V.S., Feldman R.F. Concrete admixtures handbook. Properties, Science, and Technology // Noyes Publication. USA. 1984, 575 p.

7. STB 1335-2002 Stressing cement. Specifications.

8. Obolewicz J.: Evolution of quality in technique, Safety Engineering of Anthropogenic Objects ISSN 2450-1859 e-ISSN 2450-8721 No. 2 (2017) pp. 8-15.

9. Obolewicz J. and Dąbrowski A.: An application of the Pareto Method in Surveys to Diagnose the Managers and Workers Perception of Occupational Safety and Health on Selected Polish Construction Sites, International Journal of Occupational Safety and Ergonomics (JOSE) Vol. 23, no 3 (2017), s.43. 